\title{
ROLE OF LABELS REFERRING TO QUALITY AND COUNTRY OF ORIGIN IN FOOD CONSUMERS' DECISIONS
}

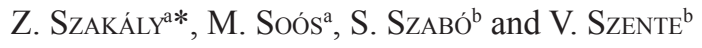 \\ a Institute of Marketing and Commerce, Faculty of Economics, University of Debrecen, \\ H-4032 Debrecen, Böszörményi u. 138. Hungary \\ ${ }^{\mathrm{b}}$ Department of Marketing and Commerce, Institute of Marketing and Management, Faculty of Economic Science, \\ University of Kaposvár, H-7400 Kaposvár, Guba S. u. 40. Hungary
}

(Received: 23 August 2014; accepted: 18 January 2015)

Within a survey made of Hungarian awareness of, attitudes towards, and preferences for food labels and pricing, this study focused on consumers' reactions to quality and country of origin labels. Data were collected with a standard questionnaire, face-to-face interviews (1000 participants) in the respondents' home. It became obvious that consumers were looking for information about quality (rating its importance at 4.04) on packages, but information about origin (3.94) and production (3.89) was also important to them. The capability of respondents to spontaneously recall country of origin and quality labels was very limited: $35.5 \%$ of all respondents could not name any such labels. The best known label was "Hungarian Product" (30.5\%), which was recognized by up to $90 \%$ of the respondents after they were shown it. Many consumers were ready to pay premium for products bearing this label (31.7\%). According to our results, information about quality is important to consumers, but they do not look for it deliberately, and only a few consumers ascribe a higher value to products with labels bearing this information. There is a pressing need to increase consumers' confidence for trademarks through dissemination of reliable information.

Keywords: label, quality, consumer preferences, country of origin, food consumer

In lots of European countries domestic products have significant benefits over import products among consumers. It is due to the fact that consumers associate good quality products mainly with products made in their own country (SoeIro, 2006; ŠtrossovÁ, 2006). France and Austria provide a perfect example for this (BÉKÉs, 2000; Keller, 2006; GFK, 2012; Oekonsult, 2012; Meas et al., 2014), where consumers prefer domestic products. In most countries a form of "food nationalism" is expressed, which leads consumers to prefer products of national or regional origin (OPTEM, 2005). A common feature of these countries is that in order to help consumers make conscious decisions a label system proving the national origin has been created, which basically concentrates on two main fields. One of them proves the country of origin, the other one proves quality.

Willingness to pay premium has already been tested in several researches in the course of using food labels. According to American results, an average household spends 184 dollars more on beef a year if they find a label on the product proving that it is controlled American (Loureiro \& UMberger, 2003). In a research carried out in Greece willingness to pay premium was tested in case of wines with labels of origin. It has been stated that those shoppers who are not devotees of a certain brand or quality are willing to pay even double price for products with labels of origin (SKURAS \& VAKROU, 2002).

\footnotetext{
* To whom correspondence should be addressed.

Phone: 36-20-9681975; e-mail: szakalyzoltan@agr.unideb.hu
} 
Based on previous surveys, Hungary does not perform well in this field. According to Gyulavári and BerÁcs (1999), as well as Berács and Malota (2000), the Hungarian consumers generally think that domestic products are of lower quality than Western European or American (US) products (MALOTA, 2003). Based on the results of a survey carried out in eight countries, Hungarian consumers are the only ones who do not purchase domestic products the most frequently and who are not the most satisfied with their domestic products (MALOTA, 2003).

The main aim of the research was to analyse the role of the labels on the food products in the consumers' preference in details, with special regard to the rejection or preference of Hungarian food products. At the same time, the results can be useful for other countries as well to create their own national labelling strategies. With our results we wish to contribute to the creation of the strategic basis of a possible label, focusing on the consumers' knowledge and expectations.

We wish to remark here that our results show the situation before the so-called Hungarian product regulation (74/2012. (VII. 25) VM) came into force in 2012 (FAOLEX, 2012).

\section{Materials and methods}

The nationwide survey was carried out in 2011 involving 1000 consumers. Representativeness was ensured in case of each region, and its structure corresponded to the quota previously stated by the Hungarian Central Statistical Office.

In each region the settlement was selected randomly (simple random sampling). In the selected settlements the so-called random-walking method was used, which ensures total randomness for selecting the proper respondents. From among the residents of the visited households the so-called birthday-key helped to select the person suitable for the interview.

In order to ensure representativeness, the structure of the sample was checked according to gender and age. Since the difference between the sample and the population is maximum $\pm 3.0 \%$, weighing was not needed and the sample was representative of the structure of the population in all the four aspects (gender, age, type of settlement, and region). The division of the sample according to socio-demographic variables is demonstrated in Table 1.

Data were collected with a standard questionnaire, face-to-face interviews in the respondents' home. The questions were the following: importance of information, judgment of statements about food labels, spontaneous and aided awareness of food labels.

The questionnaires were assessed with the help of the appropriate statistical program (SPSS 13.0). The assessment of the data was based on various mathematical-statistical methods (frequency, mean, standard deviation, chi-squared test, one-way analysis of variance) fitting the topic of the research.

\section{Results and discussion}

\subsection{Searching for and importance of information on food labels}

The objective of the first question was to know if consumers check any information on the package when buying food products. A high rate of the respondents, $83.3 \%$ said yes. This information is important rather to primary food-purchasers $(86.9 \%)(\mathrm{P}<0.001)$, but it is also worthy of attention that $87.8 \%$ of women $(\mathrm{P}<0.05)$ read the information on the label. 
Table 1. The socio-demographic background of the sample

\begin{tabular}{|c|c|c|}
\hline \multirow[t]{2}{*}{ Criterion } & \multicolumn{2}{|c|}{ Division of the sample } \\
\hline & Head & $\%$ \\
\hline \multicolumn{3}{|l|}{ Total number of respondents } \\
\hline Total & 1000 & 100.0 \\
\hline \multicolumn{3}{|l|}{ Gender } \\
\hline Male & 484 & 48.4 \\
\hline Female & 516 & 51.6 \\
\hline \multicolumn{3}{|l|}{ Age } \\
\hline $18-29$ years & 245 & 24.5 \\
\hline $30-39$ years & 181 & 18.1 \\
\hline $40-49$ years & 212 & 21.2 \\
\hline $50-59$ years & 173 & 17.3 \\
\hline Over 60 years & 189 & 18.9 \\
\hline \multicolumn{3}{|l|}{ Education } \\
\hline Elementary school & 155 & 15.5 \\
\hline Vocational school & 290 & 29.0 \\
\hline High school degree & 404 & 40.4 \\
\hline University degree & 151 & 15.1 \\
\hline \multicolumn{3}{|l|}{ Primary shopping person } \\
\hline Primary purchaser & 558 & 55.8 \\
\hline Non-primary purchaser & 442 & 44.2 \\
\hline \multicolumn{3}{|l|}{ Settlement } \\
\hline Capital city & 188 & 18.8 \\
\hline County town & 221 & 22.1 \\
\hline Town with more than 10000 residents & 179 & 17.9 \\
\hline Town with between $2000-10000$ residents & 236 & 23.6 \\
\hline Settlement with less than 2000 residents & 176 & 17.6 \\
\hline
\end{tabular}

Next the respondents were asked to mark on a one-to-five Likert scale that how important for them the information on the labels is ( 1 - not important at all, 5 - very important). The distribution of the answers is included in Table 2.

For the respondents shelf-life is the most important reaching a 4.77 mean value on the one-to-five scale. Price takes second place with 4.64, it is followed by texture (4.10) and finally by the name of the product (3.99). It is especially preferential that the country of origin, from the aspect of importance, takes the fifth place, which refers to the forming consumer awareness. Women regarded labels with shelf-life, components, and additives more important than men $(\mathrm{P}<0.001)$. The higher the level of education of the respondents is, the more important it is for them to find the ingredients and the additives indicated $(\mathrm{P}<0.05)$, but there are also justifiable differences regarding the statements referring to the country of origin, brand, trademark, health claims, and price $(\mathrm{P}<0.05)$. 
Table 2. Evaluation of the importance of information on food label $(\mathrm{n}=1000)$

\begin{tabular}{|c|c|c|}
\hline \multirow[t]{2}{*}{ Type of information } & \multicolumn{2}{|c|}{ Distribution of answers } \\
\hline & Mean & Std. deviation \\
\hline Shelf-life & 4.77 & 0.51 \\
\hline Price & 4.64 & 0.70 \\
\hline Texture & 4.10 & 1.07 \\
\hline Name of product & 3.99 & 1.01 \\
\hline Country of origin & 3.91 & 1.11 \\
\hline Food additives & 3.85 & 1.28 \\
\hline Components & 3.82 & 1.16 \\
\hline Health claims & 3.80 & 1.16 \\
\hline Volume & 3.76 & 1.17 \\
\hline Producer $^{2}$ & 3.64 & 1.11 \\
\hline Brand name $^{1}$ & 3.57 & 1.15 \\
\hline Trademark $^{3}$ & 3.52 & 1.15 \\
\hline Allergens & 3.42 & 1.34 \\
\hline Energy content & 3.21 & 1.24 \\
\hline
\end{tabular}

${ }^{1}$ Brand name of the product

${ }^{2}$ Name of the producer

${ }^{3}$ Community trademark

Our results are supported by the research of VERBEKE and RoOSEN (2009) based on the pan-European model about origin, quality, and traceability, according to which first is label referring to quality (shelf life is especially important as a compulsory element), it is followed by the label of origin, and the least important is traceability.

\subsection{Spontaneous and aided awareness of food labels, consumer preferences}

Next we surveyed the preferences connected to quality and origin-labelling. To specify the preferences exact statements were read out to the respondents and they were requested to give answers on a one-to-five scale ( 1 - do not agree at all, 5 - totally agree). Table 3 shows the relating statistical information in decreasing order of the means of all responses.

Based on data of the table, it has turned out that consumers mainly search information referring to quality: almost three-quarters $(73.5 \%)$ of the interviewed people totally agreed or mostly agreed with the statement, altogether they rated the statement a mean value of 4.04. It was the second most important for the respondents to find information about the country of origin (3.94) and about production (3.89) on the label. Statements referring to trust are in the midfield: consumers trust local and regional products the most (3.68), followed by trademarks (3.55) and independent qualifying organizations (3.40). Consumers are the least interested in food kilometres (2.34) and also the way the animals, from which the product is made, are fed (2.83). The outlined tendency is supported by the research of the Special Eurobarometer (2014); for $62 \%$ of the Hungarians the sustainment of agriculture is important from the aspect of food safety, environmental protection, and animal welfare. 
Table 3. Respondents' judgment of statements about food labels $(\mathrm{n}=1000)$

\begin{tabular}{|c|c|c|}
\hline \multirow[t]{2}{*}{ Statements } & \multicolumn{2}{|c|}{ Distribution of answers } \\
\hline & Mean & $\begin{array}{l}\text { Std. } \\
\text { deviation }\end{array}$ \\
\hline It is important to indicate information about quality on food products. & 4.04 & 1.02 \\
\hline It is important to indicate information about the country of origin on food products. & 3.94 & 1.07 \\
\hline $\begin{array}{l}\text { It is important to indicate information about the production of the product on food } \\
\text { products. }\end{array}$ & 3.89 & 1.14 \\
\hline Local and regional products create confidence inside me. & 3.68 & 1.12 \\
\hline We need trademarks because they create confidence inside me. & 3.55 & 1.20 \\
\hline $\begin{array}{l}\text { I have a higher confidence for food products with labels of independent qualifying } \\
\text { institutes. }\end{array}$ & 3.40 & 1.35 \\
\hline $\begin{array}{l}\text { If I can, I buy food products that include information about that "the animal was } \\
\text { raised in natural farm conditions" on their packages. }\end{array}$ & 3.07 & 1.39 \\
\hline $\begin{array}{l}\text { If I can, I buy food products that include information about that the animal was fed } \\
\text { on specific forage on their packages. }\end{array}$ & 2.83 & 1.32 \\
\hline $\begin{array}{l}\text { If I can, I buy food products that include information about food kilometres } \\
\text { (distance of transport) on their packages. }\end{array}$ & 2.34 & 1.34 \\
\hline
\end{tabular}

Later on, the respondents were asked to list labels spontaneously that refer to quality or country of origin on the food products. The $35.5 \%$ of them were unable to mention such a label, $34.0 \%$ could mention one, $22.8 \%$ two, and $7.9 \%$ three labels. The division of the frequency of labels with more than $1 \%$ mentioning is included in Table 4 in decreasing order of the values.

Table 4. Distribution of spontaneous mentions of food labels $(n=1000)$

\begin{tabular}{|c|c|c|c|c|c|c|c|}
\hline \multirow[t]{2}{*}{ Number } & \multirow[t]{2}{*}{ Answer categories } & \multicolumn{2}{|c|}{ First mention } & \multicolumn{2}{|c|}{ Second mention } & \multicolumn{2}{|c|}{ Third mention } \\
\hline & & Head & $\%$ & Head & $\%$ & Head & $\%$ \\
\hline 1. & Hungarian Product ${ }^{1}$ & 305 & 30.5 & 62 & 6.2 & 7 & 0.7 \\
\hline 2. & Forum of Excellent Products ${ }^{2}$ & 71 & 7.1 & 41 & 4.1 & 8 & 0.8 \\
\hline 3. & Made in Hungary & 61 & 6.1 & 31 & 3.1 & 10 & 1.0 \\
\hline 4. & Quality Product from Hungary ${ }^{3}$ & 53 & 5.3 & 32 & 3.2 & 6 & 0.6 \\
\hline 5. & Hungarian flag & 50 & 5.0 & 34 & 3.4 & 7 & 0.7 \\
\hline 6. & Hungarian Poultry ${ }^{4}$ & 39 & 3.9 & 29 & 2.9 & 8 & 0.8 \\
\hline 7. & EU & 12 & 1.2 & 3 & 0.3 & 0 & 0.0 \\
\hline 8. & Environmental friendly Product ${ }^{5}$ & 12 & 1.2 & 20 & 2.0 & 14 & 1.4 \\
\hline 9. & Organic & 5 & 0.5 & 14 & 1.4 & 8 & 0.8 \\
\hline
\end{tabular}

${ }^{1}$ The "Hungarian product" trademark can be used with processed food if all the ingredients used for production originate from Hungary and during production all the production steps were carried out in Hungary. The "Domestic product" trademark can be indicated on the packing of a Hungarian food product if more than $50 \%$ of the used ingredients are "Hungarian products" and each step of the production was carried out in Hungary. The "Domestically produced product" trademark appears on those food products that mostly include imported ingredients, but each processing step was carried out in Hungary.

${ }^{2}$ The trademark was used for the uniform differentiating labelling of excellenct products. Today it is not used.

${ }^{3}$ A non-existent trademark exists only in the consumers' sense.

${ }^{4}$ A product with the trademark was produced by a Hungarian producer, it went through a strict quality control and it was made of Hungarian raw materials.

${ }^{5}$ The trademark guarantees that the product was made in an environmental friendly way. 
Most of the interviewed people are aware of the "Hungarian Product" (Magyar Termék) label, $30.5 \%$ of them mentioned this label spontaneously first. "Forum of Excellent Products" (Kiváló Áruk Fóruma) means a label of quality products for far fewer people (7.1\%), and the label "Made in Hungary" (Magyarországon gyártották) means a reference to origin or quality for only $6.1 \%$ of the respondents. "Quality Product from Hungary" (Kiváló Magyar Áru) and the "Hungarian flag" (Magyar Zászló) labels were mentioned by hardly 5\% of the respondents, and even fewer mentioned the labels "Hungarian Poultry" (Ellenörzött Magyar Baromfi), "EU", "Environmental friendly Product" (Környezetbarát Termék), and "Organic" (Orgamikus, bio). The answers given to the question showed a significant connection with the level of education $(\mathrm{P}<0.05)$, income status $(\mathrm{P}<0.001)$, and also the type of settlement $(\mathrm{P}<0.001)$. Austria can provide us an example, where the spontaneous knowledge of the label of origin and quality was $41 \%$ in 2008, and 46\% in 2011 (AMA-MARKETING, 2013).

This group of questions also tested the respondents' awareness of labels. The respondents were invited to select from twelve labels those they had already met before. The results can be seen in Table 5 .

Table 5. Aided awareness of food labels $(\mathrm{n}=1000)$

\begin{tabular}{lcc}
\hline Answer categories & \multicolumn{2}{c}{ Distribution of answers } \\
\cline { 2 - 3 } Hungarian Product & Head & 90.0 \\
Hungarian flag & 900 & 71.9 \\
Quality Food from Hungary ${ }^{1}$ & 719 & 71.9 \\
Made in Hungary & 719 & 69.9 \\
Forum of Excellent Products & 699 & 66.6 \\
Hungarian Poultry & 666 & 57.2 \\
Environmental friendly Product & 572 & 54.4 \\
Oval shape HU label & 544 & 39.6 \\
Quality Hungarian Pork & 396 & 31.9 \\
Milk Heart & 319 & 18.5 \\
Biokontroll-HU-01 & 185 & 10.2 \\
Protected Geographical Indication & 102 & 4.5 \\
\hline
\end{tabular}

${ }^{1}$ The trademark distinguishes from the other products those products that meet the high quality standards.

From the presently used labels most consumers recognised the "Hungarian Product" label (90.0\%). The collective label of the Hungarian Collective Agricultural Marketing Centre, the "Quality Food from Hungary" (Kiváló Magyar Élelmiszer) pictogram, was known to $71.9 \%$ of the respondents, in a tie with the "Hungarian flag", not much ahead of the labels "Made in Hungary" (69.9\%) and the "Forum of Excellent Products" (66.6\%). From the sectorial-collective labels the most recognised are "Hungarian Poultry" (57.2\%) and "Quality Hungarian Pork”(Minőségi Magyar Sertéshús) (31.9\%). The knowledge of the labels showed a significant correlation with the respondents' income status and type of settlement $(\mathrm{P}<0.05)$. 


\section{Conclusions}

Based on the results of our research, quality and country of origin labels are relatively important for the consumers, independently of whether the consumer is a primary foodpurchaser or not. However, the spontaneous awareness towards these labels is low, just a few consumers trust them, and their willingness to pay premiums for them is also minimal. To understand the reasons behind these results requires further research. One strategy to follow in this situation can be to increase the intrinsic value of labels. To reach this, authentic information is necessary to increase trust in labels, it is necessary to make consumers more aware of the importance of shopping products with labels, and consumers also have to be motivated and oriented to buy products with labels. This task has to be undertaken by organizations dealing with Hungarian collective agricultural marketing that have a key role in increasing the domestic consumption of Hungarian products.

The researches of recent years (SZAKÁLY et al., 2009, 2014) have proven that a positive tendency has started amongst the Hungarian consumers. According to the two researches, in 2014 Hungarian origin takes a more prominent place among the factors that influence food preference compared to 2009, while the preference of import products has moved to the last place. That is supported by a recent study published by the SPECIAL Eurobarometer (2014). In the case of dairy and meat products, the labelling of the place of origin is judged more important by the Hungarians than by the average EU 28.

It is necessary to strengthen the Hungarian consumers' relationship to domestic products. A key to success can be the regulation introduced in 2012 (74/2012. VM - Decree of the Ministry of Rural Development) on the use of certain voluntary distinctive labels on food products. Under this regulation, labels like "Hungarian product", "Domestic product", and "Domestically produced product" can be used voluntarily (FAOLEX, 2012). The results of our research confirm that Hungarian collective marketing should increase the acceptance and consumption of Hungarian products by targeting the patriot-type consumers.

This research was made with the support of INNOTÁRS 08-2-2009-0028 project.

\section{References}

AMA-MARKeting (2013): Bekanntsheitgrad des AMA-Gütesiegel. Available at http://www.ama-marketing.at/home/ groups/7/Bekanntheit Guetesiegel.pdf. (last accessed: 20 May 2013)

BÉKÉs, T. (2000): Országképünk a francia agrár-és élelmiszerpiacon. (The image of our country on the French agricultural and food market.) MSc Thesis. Szent István University. Gödöllö, 93 pages.

BerÁcs, J. \& Malota, E. (2000): Fogyasztói etnocentrizmus, az etnocentrizmus és az országeredet imázs kapcsolata a termékválasztásban. (Connection between consumer ethnocentrism, ethnocentrism and country of origin image in product selection). Vezetéstudomány, 31(4), 25-38.

FAOLEX (2012): Decree No. 74 of 2012 (VII. 25.) VM of the Ministry of Rural Development on the use of certain voluntary distinctive signs on food. Available at http://faolex.fao.org/. (last accessed: 21 December 2014)

GFK (2012): Consumer market study on the functioning of the meat market for consumers in the European Union. GFK EU 3C Research Project. pp. 1-61.

GyulavÁRI, T. \& BerÁcs, J. (1999): Magyarország és Svédország termékeinek megítélése a budapesti lakosság körében. (Judgment of Hungarian and Swedish products among the inhabitants of Budapest.) Marketing \& Menedzsment, 33(6), 31-37. 
KeLLER, V. (2006): French experiences and results regarding foodstuffs with protected geographical origin. XV. Food Quality Control Scientific Conference. EOQ MNB. Debrecen. pp. 84-95.

Loureiro, M.L. \& UMBERGER, W.J. (2003): Estimating consumer willingness to pay for country-of-origin labeling. J. Agr. Resour. Econ., 28, 287-301.

MALотA, E. (2003): A sztereotípiák, az etnocentrizmus és az országeredet imázs hatása a hazai és a külföldi termékek megítélésére. (The image impact of stereotypes, ethnocentrism, and country of origin on the judgment of domestic and foreign products.) ( $\mathrm{PhD})$ dissertation. Budapest University of Economics and Public Administration. pp. 4-238.

Meas, T., Hu, W., Grebitus, C. \& Colson, G. (2014): The effects of country of origin image and patriotism on British consumers' preference for domestic and imported beef. AAEA Annual Meeting, Minneapolis, pp. 1-29.

Oekonsult (2012): ...lieber aus der Region. Research Report. Baden, pp. 1-25. Available at http://www.oekonsult. eu/regional-essen-mailfile.pdf. (last accessed: 20 May 2013)

OPTEM (2005): The European consumers' attitudes regarding product labelling. Qualitative Study, European Commission, pp. 1-108.

Skuras, D. \& Vakrou, A. (2002): Consumers' willingness to pay for origin labeled wine: A Greek case study. Brit. Food J., 104, 898-912.

SoEIro, A. (2006): Portugal experiences and results concerning food products with Protected Geographical Origin. $X V$. Food Quality Control Scientific Conference. EOQ MNB. Debrecen. pp. 60-62.

Special Eurobarometer 410 (2014): Europeans, agriculture and the Common Agricultural Policy (CAP). European Commission, 126 pages.

ŠTrossovÁ, K. (2006): EU Regulations of PDO, PGI and TSG. XV. Food Quality Control Scientific Conference. EOQ MNB. Debrecen. pp. 12-26.

SZAKÁly, Z., JasÁk, H., Soós, M., FehÉr, A. \& Polereczki, Zs. (2014): Fogyasztói etnocentrizmus a Hungarikumok piacán. (Consumer ethnocentrism on the market of Hungaricums.) To support national values and the collection, research, promotion, preservation, and maintenance of Hungaricums. HUNG-2013. pp. 1-55.

Szakály, Z., Szente, V., Szigeti, O., Fülöp, N. \& Polereczki, Zs. (2009): Az etnocentrikus fogyasztói magatartás vizsgálata Magyarországon. (Testing ethnocentric consumer behavior in Hungary.) Research report. Ministry of Agriculture and Rural Development. Agricultural Marketing Centre. Budapest-Kaposvár, 100 pages.

VERBEKE, W. \& RoOSEN, J. (2009): Market differentiation potential of country-of-origin, quality and traceability labeling. The Estey Centre Journal of International Law and Trade Policy, 10(1), 20-35. 